\title{
Antispasmodic and antidiarrhoeal activity of the fruit of Rosa moschata $(\mathrm{J})$
}

\author{
Niaz Ali ${ }^{*}$, Hina Alam ${ }^{1}$, Aslam Khan ${ }^{1}$, Ghayour Ahmed ${ }^{2}$, Wadood Ali Shah ${ }^{3}$, Muhammad Nabi ${ }^{1}$ \\ and Muhammad Junaid ${ }^{3}$
}

\begin{abstract}
Background: The fruit of Rosa moschata has traditionally been used for the treatment of abdominal spasm and diarrhoea. Therefore, the aim of this study was to investigate mechanism(s) responsible for its medicinal use in gut spasm and diarrhea.

Methods: Hydro-methanolic extract of Rosa moschata (Rm.Cr) was studied in isolated rabbit's jejunal preparations for possible antispasmodic activity. Based upon in vitro relaxant activity in isolated gut preparations, in vivo antidiarrheal activity was carried out in mice to confirm its antidiarrheal effect. Acute toxicity study was performed to determine safe dose range before in vivo experiments.

Results: In isolated rabbits' jejunal preparations, Rm.Cr inhibited the spontaneous and high $\mathrm{K}^{+}$-induced contractions with respective $E_{50}$ values of $0.66(0.44-0.97 ; n=5)$ and $2.28 \mathrm{mg} / \mathrm{mL}(1.43-3.62 ; n=5)$, like that of verapamil. This suggests the presence of calcium channel blocking (CCB) activity as a possible mode of action. The $\mathrm{Ca}^{++} \mathrm{Channel}^{2}$ blocking activity was further confirmed when pre-treatment of isolated jejunums with $\operatorname{Rm} . \operatorname{Cr}(1-5 \mathrm{mg} / \mathrm{mL})$ caused a rightward shift in the $\mathrm{Ca}^{++}$concentration-response curves (CRCs), similar to verapamil. Rm.Cr was safe up to $2000 \mathrm{mg} / \mathrm{kg}$ for in vivo acute toxicity. Rm.Cr provided 55\% and 80\% protection from diarrhoea in respective doses of $100 \mathrm{mg} / \mathrm{kg}$ and $1000 \mathrm{mg} / \mathrm{kg}$. These data indicates that the crude extract of Rosa moschata possesses $\mathrm{Ca}^{++}$ antagonist-like constituent(s), which explains its inhibitory effect on gut motility; a mechanism that underlies its antidiarrheal and antispasmodic activities.

Conclusion: The study shows that the crude extract of fruits of Rosa moschata possesses antispasmodic effects mediated possibly through voltage gated $\mathrm{Ca}++$ channel blockade, which provides sound pharmacological base to its medicinal use in gut spasms and diarrhoea, though additional mechanism(s) cannot be ruled out.
\end{abstract}

Keywords: Rosa moschata, Antidiarrhoeal, Antispasmodic, $\mathrm{Ca}^{++}$antagonist, Verapamil

\section{Background}

Plants have been used from a long while for the treatment of various diseases and 80,000 species out of 250,000 of higher plants are used medicinally [1]. The use of natural products are considered safe as compared to synthetic products, so the beliefs on using the synthetic products is decreasing compared to natural products [2]. Herbal medicines show potential uses in future because most of the plants, their activities and pharmacological activities have not being explored completely [3].

\footnotetext{
* Correspondence: niazpharmacist@yahoo.com

${ }^{1}$ Department of Pharmacology, Institute of Basic Medical Sciences, Khyber Medical University, Peshawar, Pakistan

Full list of author information is available at the end of the article
}

Rosa moschata belongs to a family called rosaceae [4]. There are more than 120 species of rose. Seven species of rosaceae are found in Malakand region [4,5]. The local names are "zangley gulap", "kurach", "Qorach" in Pakistan and "kuja", "Kojai", "kunia" in India [4,6-10]. It is small perennial climbing shrub and its flowers, leaves, fruits or whole plant is used medicinally. It is traditionally used in eyes' disorders, diarrhoea, wounds healing, stomach disorders, delivery cases and in bilious affections [6,8,11-13]. It has also vermicidal properties [9]. Folklorically, the Rosa moschata is also used as laxative agent [14]. However, as laxative agent, no specific "part used" have been refernced thereby providing a space for resaerchers to explore. Its 
antioxidant property has been explored on scientific background [15].

The fatty acid composition of Rosa moschata has been determined by gas chromatography and then confirmed by the gas chromatography mass spectroscopy (GC-MS) which contains stearic acid, palmitic acid, oleic acid, margaric acid, linoleic acid and linolenic acid. The other isolated compounds of Rosa moschata are Vitamin A, C, E, flavonoids and essential oil $[5,16,17]$. Other species of the genius rosa like Rosa damascena have been reported to have spasmogenic (low concentration) and spasmolytic activity (in higher concentration) on rats' ileum [18]. In addition, relaxant activity of Rosa damascena on guinea pig tracheal chains has been reported [19].

Due to its medicinal use in gut spasm and diarrhea, the current work focused to provide pharmacological basis for the medicinal use of Rosa moschata in gut spasms.

\section{Methods}

\section{Plant materials and extraction of crude extract}

Fresh fruits of Rosa moschata were collected from Malakand region and authenticated by Professor Dr. Jehandar Shah, ex vice chancellor and plant taxonomist, University of Malakand, Pakistan. A voucher specimen (RM-2103) has been deposited in the Department of Pharmacology, Khyber Medical University, Peshawar.

Plant materials, free of adulterants, were repeatedly extracted (3 times) with commercial grade methanol (80\%) at room temperature and the combined extract was evaporated in rotary evaporator at $35-40^{\circ} \mathrm{C}$ to a semisolid mass, the crude extract of Rosa moschata. The extract (free of solvent) was solubilized in normal saline and distilled water for the in-vivo and in-vitro experiments, respectively.

\section{Drugs and standards}

Analytical grade chemicals were used throughout these experiments. Acetylcholine was purchased from BDH, Poole, England, which was used for the maintenance of tissues at quiescent doses. Rest of the chemicals were of E Merck grade. Stock solutions of all the chemicals were made in distilled water and the dilutions were made fresh in normal saline on the days of experiments.

\section{Animals}

BALB/C mice (weighing 25-30 g, hired from NIH, Islamabad) and local breed rabbits (weighing $1.5-2 \mathrm{~kg}$ ) of either sex were housed at the animal house of the Institute of Basic Medical Sciences, Khyber Medical University, Peshawar, Pakistan under a controlled environment $\left(23-25^{\circ} \mathrm{C}\right)$. The animals were kept in respective cages and were fasted overnight before starting the experiments. Advanced Study \& Research Board and
Ethical Board of Khyber Medical University approved the study protocols (ASRB000152/AA/IBMS/20/03/2014).

\section{Preliminary phytochemical screenings}

Plant extracts was tested for various active principles i.e. Triterpenoids, Steroids, Glycosides, Saponins, Alkaloids, Flavonoids, Tannins, and Carbohydrate using different tests such as Liebermann Burchard test was used for steroids and triterpenoids, Keller Killiani and Bromine water test for Glycosides, Foam test for Saponins, Hager's test for Alkaloids, Ferric chloride test, Alkaline reagent test and Lead acetate solution test for Flavonoids, Gelatin test for Tannins, Biuret test for proteins and Benedict's test for carbohydrates described by Bhaddray, 2012 [20].

\section{Acute toxicity}

Acute toxicity was performed as reported previously by Ali et al. 2013 [21]. Briefly, animals were divided in groups of 5 mice in each group. The test was performed in test doses of 1, 10, 1000 and $2000 \mathrm{mg} / \mathrm{kg}$, given through intraperitoneal route. Another group of mice was administered normal saline which served as negative control. The mice were allowed food and water ad libitum during 24 hours test period. The animals were under regular observations for gross behavioral changes and mortality during the said period.

\section{Isolated tissue preparations}

The isolated tissues experiments were performed in accordance with protocols established in our lab [21,22]. Rabbits were fasted for 24 hours before the experiments with free access to water. Then rabbits were sacrificed by cervical dislocation, the abdomens were cut open and the jejunal portions were isolated. Preparations of about $2 \mathrm{~cm}$ long were mounted in $15 \mathrm{~mL}$ tissue baths containing Tyrode's solution maintained at $37^{\circ} \mathrm{C}$, constantly aerated with carbogen (a mixture of 5\% carbon dioxide in oxygen).

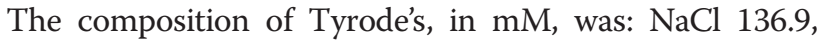
$\mathrm{KCl}$ 2.7, $\mathrm{NaHCO}_{3}$ 11.9, $\mathrm{MgCl}_{2}$ 1.1, Glucose 5.6, $\mathrm{NaH}_{2} \mathrm{PO}_{4}$ 0.4 , and $\mathrm{CaCl}_{2} 1.8$ (pH 7.4). Tension of about $1.0 \mathrm{~g}$ of preload was applied to tissues and subsequently kept undisturbed for $30 \mathrm{~min}$ for stabilization. Upon stabilization of the isolated jejunal tissues, reproducible control responses of acetylcholine $(0.3 \mu \mathrm{M})$ were obtained.

Under these experimental conditions, rabbits' jejunums exhibited spontaneous contractions, allowing testing for possible relaxant (spasmolytic) activity directly without use of a spasmogen or an agonist.

\section{Calcium antagonist activity}

To assess whether the spasmolytic activity of the test substances was mediated through voltage gated $\mathrm{Ca}++$ channels blockade, high concentration of $\mathrm{K}+(80 \mathrm{mM})$, as $\mathrm{KCl}$, was used to depolarize the preparations [21,22], which 
produced sustained contractions. Cumulative dosing of verapamil (standard) and extract of Rm.Cr was then added to isolated tissue baths to obtain concentration-dependent inhibitory responses. The relaxation of isolated jejunal tissues, pre-contracted with $\mathrm{K}+$ was expressed as percent of the control pre-contractions.

$\mathrm{Ca}^{++}$channel blocking activity of plant extract was confirmed when the tissues were first stabilized in normal Tyrode's solution and normal Tyrode's solution was replaced with $\mathrm{Ca}^{++}$free Tyrode's solution containing EDTA $(0.1 \mathrm{mM})$ for 30 minutes. EDTA chelates the $\mathrm{Ca}^{++}$. This solution was then replaced with $\mathrm{K}^{+}$-rich and $\mathrm{Ca}^{++}$-free Tyrode's solution, having the following composition: $\mathrm{NaCl}$ 91.04, $\mathrm{KCl} 50, \mathrm{NaHCO}_{3} 11.90, \mathrm{MgCl}_{2}$ 1.05, glucose 5.55, $\mathrm{NaH}_{2} \mathrm{PO}_{4} 0.42$ and EDTA $0.1 \mathrm{mM}$. Control concentrationresponse curves (CRCs) of $\mathrm{Ca}^{++}$were obtained after an incubation period of 30 minutes. When the CRCs of $\mathrm{Ca}^{++}$were found superimposable (usually after two cycles), the tissues were then pretreated with $\mathrm{Rm}$.Cr for 60 minutes to test the possible $\mathrm{Ca}^{++}$channel blocking effect. The CRCs of $\mathrm{Ca}^{++}$were reconstructed in the presence of different concentrations of the plant extract and verapamil (standard).

\section{Data recording and Interpretation}

Isotonic Transducer (MLT 0210/A Pan Lab) were used to record the intestinal recordings, connected with Power lab (Model No: 4/26 T) AD Instruments, Australia. Bridge Pod Amplifier connected with the Power lab was used for amplification of the intestinal responses.

Lab Chart 7 supplied with the power Lab was used to record and interpret the data.

\section{Effects on castor oil-induced diarrhea}

Based on positive relaxant activity of $\mathrm{Rm}$. Cr on gut mortality, the in-vivo antidiarrheal activity of the extract was carried out following the methods as described in our previous articles with slight modifications [23]. In this study, Balb C albino mice were kept on overnight fasting. Five groups of the mice were made and kept in five different steel cages containing four mice in each. Bottom of each cage was covered with blotting sheet. Normal saline $(10 \mathrm{~mL} / \mathrm{kg}$, orally) was given to first group and labeled as the negative control. Rm.Cr was administered orally by intra-gastric feeding needle to the second, third and fourth group in doses of 100,300 and $1000 \mathrm{mg} / \mathrm{kg}$ keeping in view the acute toxicity results. Loperamide $(10 \mathrm{mg} / \mathrm{kg}$ p.o.) was given to the fifth group as positive control. $10 \mathrm{~mL} / \mathrm{kg}$ of castor oil (p.o.) was given to all the groups after one hour post extract/test sample treatment. All the groups were then observed for the presence of diarrhoeal droppings in the individual cages for 4 hours after ingestion of the castor oil. Based on the number of
Table 1 Phytochemical screenings of Rosa moschata

\begin{tabular}{lll}
\hline s. no & Phytochemicals & Remarks \\
\hline 1. & Alkaloids & - \\
2. & Flavonoids & + \\
3. & Tannins & + \\
4. & Saponins & + \\
6. & Carbohydrate & + \\
5. & Quinones & - \\
7. & Sterols & - \\
8. & Phenolics & + \\
9. & Proteins & + \\
10. & Terpenoids & + \\
11. & Glycosides & - \\
\hline
\end{tabular}

dry and wet feces, percent protection against the castor oil-induced diarrhoea was calculated for each group.

\section{Data analysis}

Data are expressed as mean \pm standard error of the mean (SEM) and the median effective concentrations $\left(\mathrm{EC}_{50}\right)$ values were given with $95 \%$ confidence intervals (CI) using Graph Pad Prism.

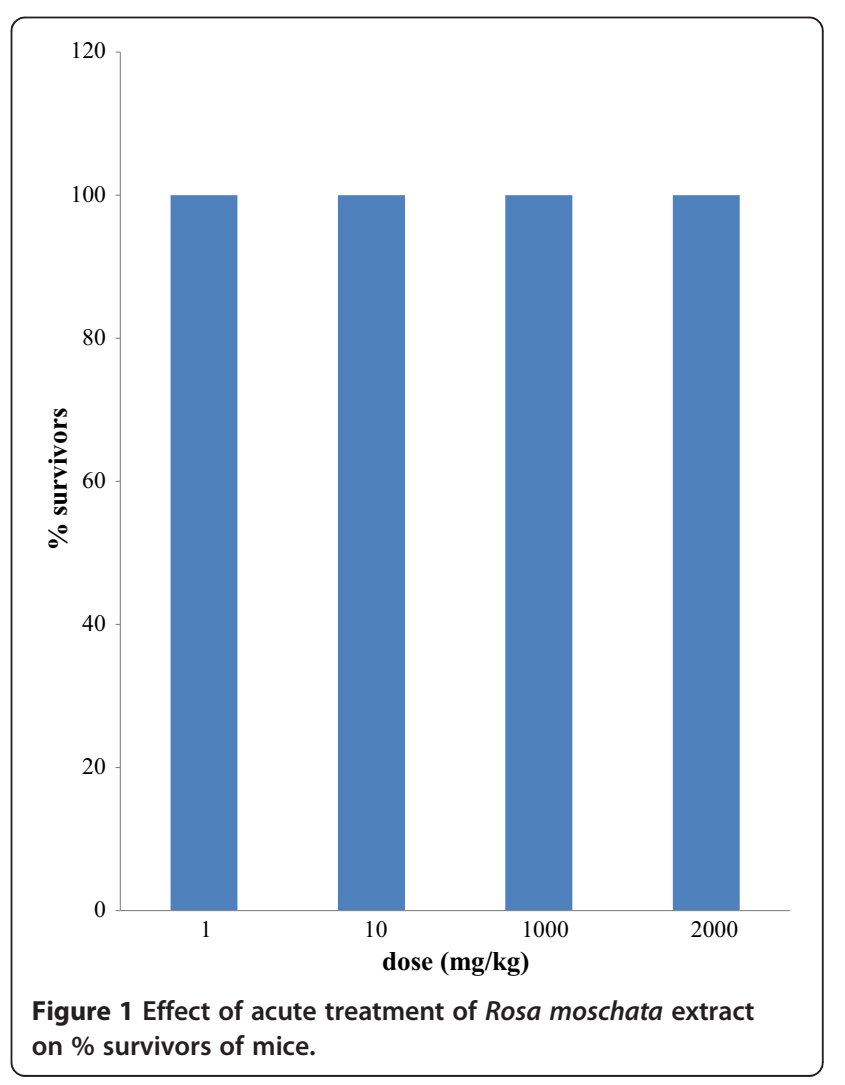




\section{Results and discussion}

Upon preliminary phytochemical screenings, Rosa moschata tested positive for presence of tannins, flavonoids, saponins, phenolics, proteins and terpenoids. It tested negative for alkaloids, quinones, sterols and glycosides (Table 1). Acute toxicity results proved that the extract is safe up to $2000 \mathrm{mg} / \mathrm{kg}$. The percent survivors are expressed in Figure 1. This reflects good safety profile of the sample making it a possible candidate for the development of herbal products.
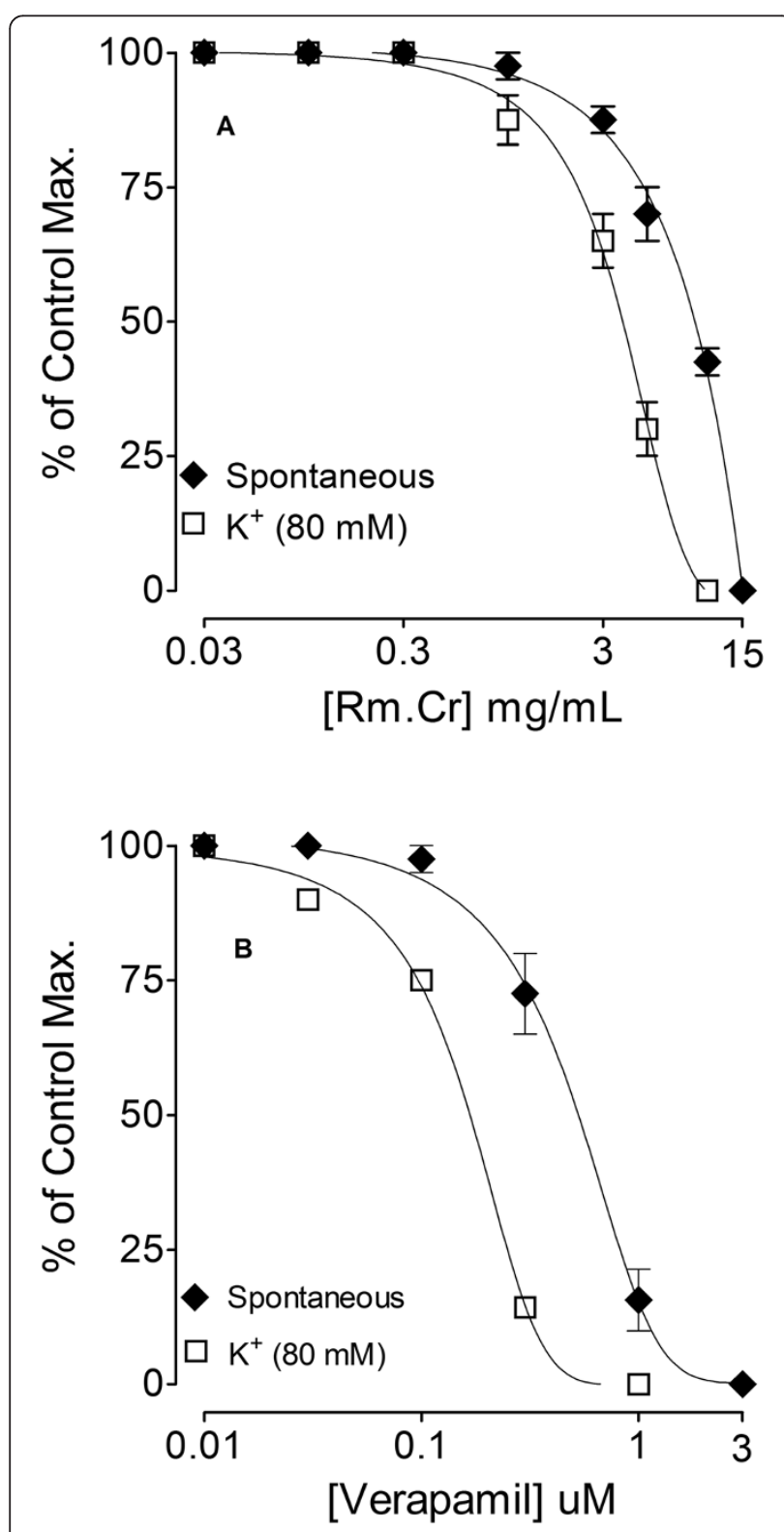

Figure 2 Concentration-response curves of; $(A)$ the crude extract of Rosa moschata (Rm.Cr), and (B) verapamil on spontaneous and high $\mathrm{K}^{+}(80 \mathrm{mM})$-induced contractions. Values shown are mean \pm SEM $(n=5)$.
As there is no study available on the antispasmodic and antidiarrheal activity of this plant, therefore, this study was undertaken to provide the pharmacological basis for its medicinal use in hyperactive gut disorders and to investigate the mechanism of its spasmolytic effect. For this purpose this study was carried out on gut motility in isolated spontaneously contracting rabbits' jejunums, where cumulative addition of crude extract of Rosa moschata caused concentration-dependent inhibition of the spontaneous and high $\mathrm{K}^{+}$induced contractions, with $\mathrm{EC}_{50}$ values of $8.21 \mathrm{mg} / \mathrm{mL}(6.66-10.12)$ and 3.93 (3.39 - 4.55), respectively (Figure 2A). In similar pattern, verapamil, a standard $\mathrm{Ca}^{++}$antagonist [22], relaxed the spontaneous and high $\mathrm{K}^{+}$induced contractions, with $\mathrm{EC}_{50}$ values $0.51 \mathrm{mg} / \mathrm{mL}(0.43-0.60)$ and $0.16 \mathrm{mg} / \mathrm{ml}$

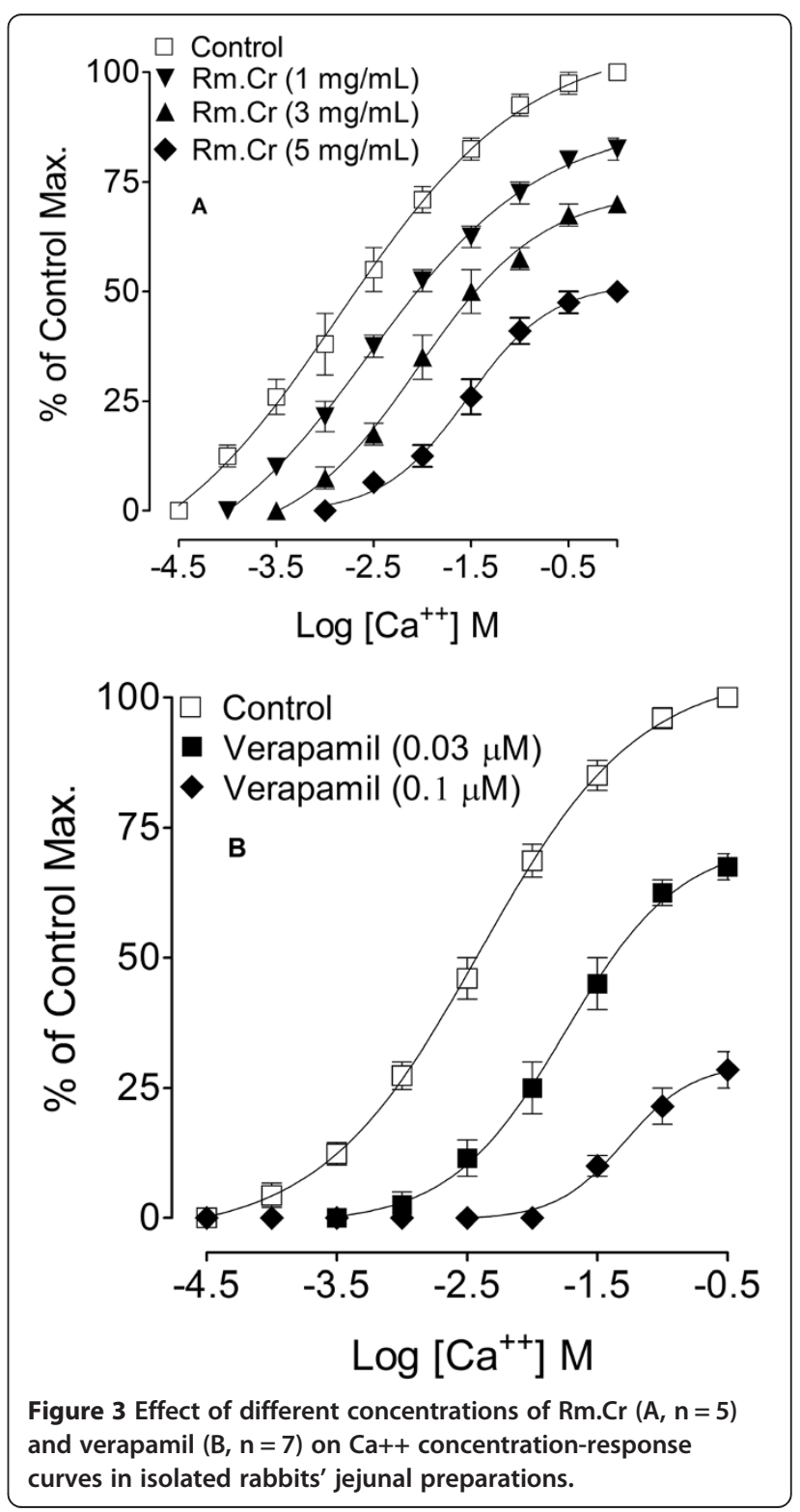




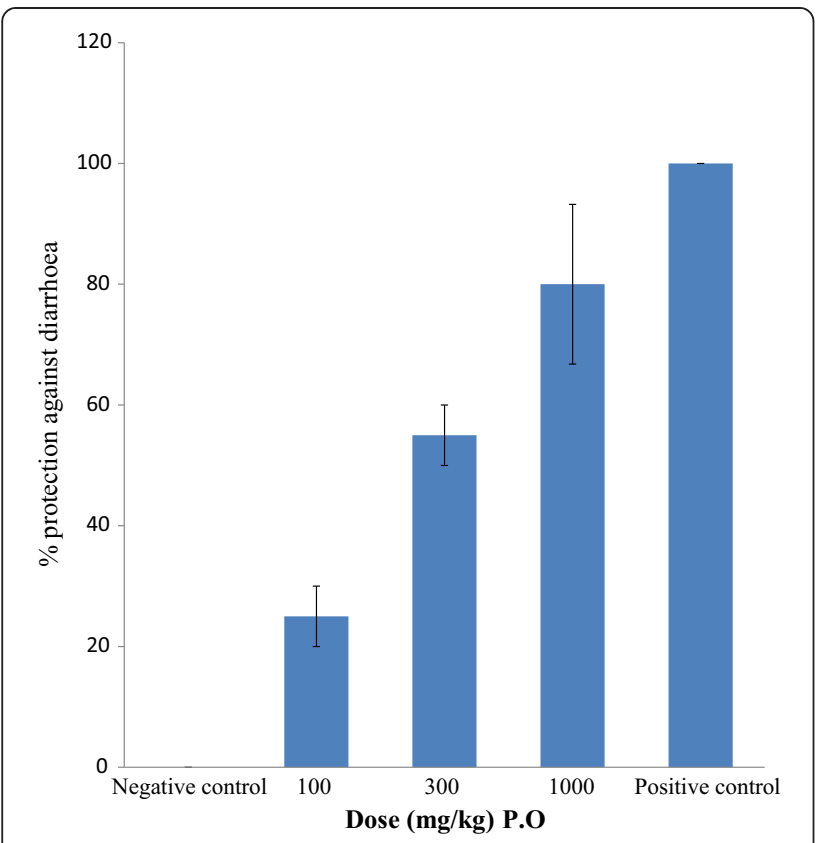

Figure 4 Effects of the crude extract of the leaves of Rosa moschata and loperamide on castor oil-induced diarrhea in mice (mean $\pm S D ; n=3$ ).

$(0.13-0.21)$, respectively (Figure $2 \mathrm{~B})$. This shows smooth muscle relaxant (antispasmodic) activity may be mediated through calcium antagonistic effect as high $\mathrm{K}^{+}(>30 \mathrm{mM})$ is known to cause smooth muscle contractions through opening of voltage-dependent L-type $\mathrm{Ca}^{++}$channels, thus allowing influx of extracellular $\mathrm{Ca}^{++}$causing a contractile effect [24] and the substance which cause inhibition of high $\mathrm{K}+$-induced contraction is considered to be an inhibitor of $\mathrm{Ca}^{++}$influx [25]. Extract of the Rosa maschata relaxed the high $\mathrm{K}+$-induced contractions, similar to that caused by verapamil (standard $\mathrm{Ca}^{++}$antagonist [26] indicating its $\mathrm{CCB}$ action. The $\mathrm{Ca}^{++}$antagonist effect of Rosa moschata was further confirmed when Rm.Cr dose dependently (1-5 $\mathrm{mg} / \mathrm{mL})$ shifted the $\mathrm{Ca}^{++}$concentration response curves to the right (Figure 3A), like that caused by verapamil (Figure $3 \mathrm{~B}$ ). $\mathrm{Ca}^{++}$antagonists have been shown to be beneficial in gut disorders resulting from hyperactivity such as diarrhoea and abdominal cramps [27]; hence the observed CCB effect justifies the medicinal use of Rosa moschata in such conditions. This observed Calcium channel blocking effect of the plant may be due to the presence of flavonoids, as evident from phytochemical screening, because the constituents of this class of compounds have been reported to have Calcium channel blocking activity [28,29], however, contribution of other compound may not be ruled out. This is the first functional study on the gut motility with possible mode of action, carried out on the fruit of Rosa moschata.
Based on the relaxant effect of Rosa moschata on spontaneous and $\mathrm{K}^{+}$induced contractions in isolated jejunal preparations, an in vivo model was used to test the extract for possible inhibitory effect on gut motility as for possible antidiarrhoeal activity. The crude extract provided protection from diarrhea in castor oil-induced diarrhea, similar to loperamide, a standard antidiarrheal agent [30]. Both extract and loperamide significantly inhibited $(\mathrm{P}<0.05)$ the frequency of defecation as well as wetting of feces when compared with the untreated group (i.e. mice which only received castor oil but neither crude extract, nor loperamide). The percent protection provided by the crude extract was $25 \pm 5,55 \pm 5$ and $80 \pm 13.2$ at doses of 30,100 and $1000 \mathrm{mg} / \mathrm{kg}$ respectively. Loperamide provided $100 \%$ protection at $10 \mathrm{mg} / \mathrm{kg}$ (Figure 4).

Hydrolysis of castor oil results in the formation of recinoleic acid [31], which produces changes in the transport of water and electrolytes resulting in a hyper secretory response and generation of a giant contraction of the intestine [32]. Thus, a potential antidiarrheal agent may exhibit its antidiarrheal effect by inhibiting either contraction of smooth muscles of the gut or electrolyte out flux [33].

\section{Conclusion}

In summary, this study shows that the crude extract of Rosa moschata possesses antispasmodic and antidiarrheal effects, mediated possibly through $\mathrm{Ca}^{++}$channel blockade, which provides sound pharmacological base to its medicinal use in diarrhoea and gut spasms, though additional mechanism(s) cannot be ruled out.

\section{Abbreviations}

Rm.Cr: Crude methanolic extract of Rosa moschata; CCB: Calcium channel blocking; CRCs: Concentration-response curves.

\section{Competing interests}

The authors declare that they have no competing interests.

\section{Authors' contributions}

NA: Data interpretation, preparation of the manuscript. HA: Performed antispasmodic activity (M.Phil Scholar). AK: helped in constructing calcium chloride curves and manuscript preparation. GA: Data acquisition. SWAS: Data acquisition and helped in Phytochemistry determination. MN: Data acquisition of antidiarrhoeal activity. MJ: helped in Phytochemistry. All the authors have read and approved the final proof of the manuscript.

\section{Acknowledgements}

The author thanks Professor Dr. Jehandar Shah for identifying the plant. The authors want to thank the Higher Education Commission of Pakistan for providing research grant no: 20-1723/R\&D/10 for establishment of pharmacology laboratory at IBMS, KMU.

\section{Author details}

${ }^{1}$ Department of Pharmacology, Institute of Basic Medical Sciences, Khyber Medical University, Peshawar, Pakistan. ${ }^{2}$ Department of Pharmacy, Kohat University of Science and Technology, Kohat, Pakistan. ${ }^{3}$ Department of Pharmacy, University of Malakand, Chakdara Dir, Lower, Pakistan.

Received: 9 September 2014 Accepted: 10 December 2014 Published: 13 December 2014 


\section{References}

1. Fabricant DS, Farnsworth NR: The value of plants used in traditional medicine for drug discovery. Environ Health Perspect 2001, 109:69.

2. Joy P, Thomas J, Mathew S, Skaria BP: Medicinal plants. Trop Horticulture 1998, 2:449-632

3. Hassan BAR: Medicinal Plants (Importance and Uses). Pharma Anal Acto 2012, 3:10.

4. Barkatullah B, Ibrar M: Plants profile of Malakand Pass Hills, District Malakand, Pakistan. Afr J Biotechnol 2013, 10:16521-35.

5. Sharma B, Singh B, Dhyani D, Verma PK, Karthigeyan S: Fatty acid composition of wild growing rose species. J Med Plants Res 2012, 6:1046-9.

6. Sharma P, Devi U: Ethnobotanical uses of Biofencing Plants in Himachal Pradesh, Northwest Himalaya, Pakistan. J Bio/ Sci 2013, 16:1957-63.

7. Sher $H$, Elyemeni $M$, Sher H, Hussain K: Ethnobotanical and economic observations of some plant resources from the Northern Parts of Pakistan. Ethnobotany Res Appl 2011, 9:27-41.

8. Ajmal S, Mohammad S, Zahid K, Bakht Z, Habib A, Alam M: Ethnomedicinal and phytoeconomic elaboration of Lilownai valley, district Shangla Pakistan. Int Res J Pharm 2012, 3:164-9.

9. Dutt B, Sharma S, Sharma K, Gupta A, Singh H: Ethnobotanical survey of plants used by Gaddi tribe of Bharmour area in Himachal Pradesh. Himalayan Ecol 2011, 19:22.

10. Kumar A, Mitra M, Singh G, Rawat G: An inventory of the flora of binog wildlife sanctuary, mussoorie, garhwal himalaya. 2012, 2(1):281-299.

11. Akhtar N, Rashid A, Murad W, Bergmeier E: Diversity and use of ethnomedicinal plants in the region of Swat, North Pakistan. J Ethnobiol Ethnomed 2013, 9:25.

12. Ali H, Sannai J, Sher H, Rashid A: Ethnobotanical profile of some plant resources in Malam Jabba valley of Swat, Pakistan. J Med Plants Res 2011, 5:4676-87.

13. Khare CP: Indian Medicinal Plants: An Illustrated Dictionary: Springer. 2007.

14. Jehanzeb K, Rooman K, Rizwana AQ: Ethnobotanical study of commonly used weeds of District Bannu, Khyber Pakhtunkhwa (Pakistan). J Med Plant Stud 2013, 2:1-6.

15. Franco D, Pinelo M, Sineiro J, Núñez MJ: Processing of Rosa rubiginosa: Extraction of oil and antioxidant substances. Bioresour Technol 2007, 98:3506-12.

16. Matthews V: New Plantsman: Royal Horticultural Society. 1994.

17. Honarvar M, Javidnia K, Khosh-Khui M: Essential oil composition of fresh and dried flowers of Rosa moschata from Iran. Chem Nat Compd 2011, 47:826-8.

18. Sadraei $H$, Asghari $G$, Emami S: Inhibitory effect of Rosa damascena Mill flower essential oil, geraniol and citronellol on rat ileum contraction. Res Pharm Sci 2013, 8(1):17-23.

19. Boskabady MH, Kiani S, Rakhshandah H: Relaxant effects of Rosa damascena on guinea pig tracheal chains and its possible mechanism(s). J Ethnopharmacol 2006, 106(3):377-382.

20. Bhandary SK, Kumari N, Bhat VS, Sharmila K, Bekal MP: Preliminary phytochemical screening of various extracts of Punica granatum peel, whole fruit and seeds. J Health Sci 2012, 2:35-8.

21. Ali N, Shah I, Shah SW, Ahmed G, Shoaib M, Junaid M, Ali W, Ahmed Z Antioxidant and relaxant activity of fractions of crude methanol extract and essential oil of Artemisia macrocephala jacquem. BMC Complement Altern Med 2013, 13:96.

22. Ali N, Ahmed G, Shah SWA, Shah I, Ghias M, Khan I: Acute toxicity, brine shrimp cytotoxicity and relaxant activity of fruits of Callistemon citrinus curtis. BMC Complement Altern Med 2011, 11:99.

23. Gilani AH, Rehman NU, Mehmood MH, Alkharfy KM: Species differences in the antidiarrheal and antispasmodic activities of Lepidium sativum and insight into underlying mechanisms. Phytother Res 2013, 27(7):1086-1094.

24. Farre AJ, Colombo M, Fort M, Gutierrez B: Differential effects of various Ca2+ antagonists. Gen Pharmacol 1991, 22:177-81.

25. Bolton TB: Mechanisms of action of transmitters and other substances on smooth muscle. Physiol Rev 1979, 59:606-718.

26. Godfraind T, Miller R, Wibo M: Calcium antagonism and calcium entry blockade. Pharmacol Rev 1986, 38:321-416.

27. Fleckenstein A: Specific pharmacology of calcium in myocardium, cardiac pacemakers, and vascular smooth muscle. Annu Rev Pharmacol Toxicol 1977, 17:149-66.
28. Pasricha PJ: Treatment Of Disorders Of Bowel Motility And Water Flux. In The Pharmacological Basis Of Therapeutics. Edited by Brunton LL, Lazo JS Parker KL. New York: McGraw-Hill New York; 2006:983-1008.

29. Carlo G, Izzo A, Maiolino P, Mascolo N, Viola P, Diurno MV, Capasso F: Inhibition of Intestinal Motility and Secretion by Flavonoids in Mice and Rats: Structure-activity Relationships. J Pharm Pharmacol 1993, 45:1054-9.

30. Revuelta MP, Cantabrana B, Hidalgo A: Depolarization-dependent effect of flavonoids in rat uterine smooth muscle contraction elicited by $\mathrm{CaCl}_{2}$. Gen Pharmacol 1997, 29:847-57.

31. Reynolds IJ, Gould RJ, Snyder SH: Loperamide: blockade of calcium channels as a mechanism for antidiarrheal effects. J Pharmacol Exp Ther 1984, 231:628-32.

32. Iwao I, Terada Y: On the mechanism of diarrhea due to castor oil. Jpn J Pharmacol 1962, 12:137-45.

33. Croci T, Landi M, Emonds-Alt X, Fur G, Maffrand JP, Manara L: Role of tachykinins in castor oil diarrhoea in rats. Br J Pharmacol 1997, 121:375-80.

doi:10.1186/1472-6882-14-485

Cite this article as: Ali et al: Antispasmodic and antidiarrhoeal activity of the fruit of Rosa moschata (J). BMC Complementary and Alternative Medicine 2014 14:485.

\section{Submit your next manuscript to BioMed Central and take full advantage of:}

- Convenient online submission

- Thorough peer review

- No space constraints or color figure charges

- Immediate publication on acceptance

- Inclusion in PubMed, CAS, Scopus and Google Scholar

- Research which is freely available for redistribution 